\title{
Silage review: Silage feeding management: Silage characteristics and dairy cow feeding behavior ${ }^{1}$
}

\author{
R. J. Grant* ${ }^{\star 2}$ and L. F. Ferraretto† \\ *William H. Miner Agricultural Research Institute, Chazy, NY 12921 \\ †Department of Animal Sciences, University of Florida, Gainesville 32611
}

\begin{abstract}
Feeding environment and feed accessibility influence the dairy cow's response to the ration and forage composition. Fiber content, physical form, and fermentability influence feeding behavior, feed intake, and overall cow metabolic and lactational responses to forage. It is possible to vary eating time of lactating dairy cattle by over $1 \mathrm{~h} / \mathrm{d}$ by changing dietary silage fiber content, digestibility, and particle size. Optimizing silage particle size is important because excessively long particles increase the necessary chewing to swallow a bolus of feed, thereby increasing eating time. Under competitive feeding situations, excessively coarse or lower fiber digestibility silages may limit DMI of lactating dairy cows due to eating time requirements that exceed available time at the feed bunk. Additionally, greater silage particle size, especially the particles retained on the 19-mm sieve using the Penn State Particle Separator, are most likely to be sorted. Silage starch content and fermentability may influence ruminal propionate production and thereby exert substantial control over meal patterns and feed consumption. Compared with silage fiber characteristics, relatively little research has assessed how silage starch content and fermentability interact with the feeding environment to influence dairy cow feeding behavior. Finally, voluminous literature exists on the potential effects that silage fermentation end products have on feeding behavior and feed intake. However, the specific mechanisms of how these end products influence behavior and intake are poorly understood in some cases. The compounds shown to have the greatest effect on feeding behavior are lactate, acetate, propionate, butyrate, ammonia-N, and amines. Any limitation in the feeding environment will likely accentuate the negative response to poor silage fermentation. In the future, to optimize feeding
\end{abstract}

Received August 22, 2017.

Accepted January 16, 2018.

${ }^{1}$ This article is part of a special issue on silage management.

${ }^{2}$ Corresponding author: grant@whminer.com behavior and dry matter intake of silage-based diets fed to dairy cattle, we will need to consider the chemical and physical properties of silage, end products of silage fermentation, and the social and physical components of the feeding environment.

Key words: silage, fermentability, feeding behavior, feed intake

\section{INTRODUCTION}

Forages fed as silage remain popular for dairy farms because they minimize loss of nutrients from harvest through storage, allow for easier feeding, and often allow greater efficiency and timeliness of feed mixing and handling on the farm than dry forages (Mahanna and Chase, 2003). Measuring the chemical composition and physical properties of silages is important for proper ration formulation and troubleshooting silage quality problems; voluminous literature exists on this topic (e.g., Kung and Shaver, 2001; Heinrichs and Kononoff, 2013). The content and fermentability of silage fiber, starch, and protein, together with fermentation end products, influence dairy cattle feeding behavior and DMI (Oliveira et al., 2017).

The physical and social environment in which the forage is fed will also have a modulating effect on the feeding and productive response by the cow (Grant and Albright, 2001). For example, Bach et al. (2008) reported on the nondietary factors that most influenced milk production among dairy farms that fed the same TMR containing corn and triticale silages. In their study, 2 of the most important factors explaining variation in milk yield among farms were routine feed push-up and feeding for TMR refusal at the end of the daily feeding cycle. Ensuring access to the feed was associated with 1.6 to $3.9 \mathrm{~kg} / \mathrm{d}$ greater milk production per cow. The results of the Bach et al. (2008) study illustrate the importance of optimizing the feeding environment and feed bunk management such that the cow will respond most productively to the nutritional value of the silage in the ration.

How silage quality interacts with feed bunk management needs to be understood to optimize the cow's 
behavioral and productive response to the silage. The objectives of our paper are to review (1) how silages of varying fiber content, digestibility, and particle size; starch content and digestibility; and fermentation end product profile influence dairy cattle feeding behavior and DMI, and (2) how the feeding environment may modulate the animal's feeding behavior and DMI response to silages of varying nutritional value.

\section{SILAGE FIBER CHARACTERISTICS, FEEDING BEHAVIOR, AND DMI}

Dietary NDF content, digestibility, and particle size influence fiber intake, chewing behavior, ruminal turnover, and efficiency of milk production (Oba and Allen, 2000). As ration fiber content increases, cows will typically spend more time eating, have longer meal length, and practice greater sorting behavior (Beauchemin, 1991). In contrast, as NDF digestibility increases, chewing time per unit of NDF often decreases (Beauchemin, 1991).

The chewing index, expressed as minutes of chewing elicited per kilogram of DM, typically decreases as forage NDF digestibility increases, particle length is shortened, or NDF content decreases. A negative linear relationship exists between DMI and the dietary chewing index for silage-based diets primarily composed of grass and grass-clover silages, alfalfa silage, corn silage, and whole-crop silages (Jensen et al., 2016). Although not reflected in the chewing index, part of the potentially negative effect of some silages on energy intake is related to low silage DM content and the negative effects of higher silage fermentation end products (Huhtanen et al., 2007). Nonetheless, it is clear that silage NDF content, digestibility, and particle size significantly influence chewing activity and DMI in ruminants (Oba and Allen, 2000).

\section{Dietary Forage Content, Fiber Digestibility, and Particle Size}

Jiang et al. (2017) observed a $1.8 \mathrm{~h} / \mathrm{d}$ greater eating time when dietary forage content increased from 40 to $70 \%$ (mixture of corn silage, alfalfa hay, oat hay, and rye hay); but rumination time only increased by $35 \mathrm{~min} / \mathrm{d}$. Interestingly, resting time decreased by $2.3 \mathrm{~h} / \mathrm{d}$. Thus, greater time eating came primarily at the expense of resting and, in fact, the greater total chewing time (eating + rumination) as forage content increased was exactly offset by lost resting time (2.3 $\mathrm{h} / \mathrm{d}$ ). This interaction between eating and resting behavior is well documented and underscores the inelastic resting requirement of dairy cattle (Jensen et al., 2005; Munksgaard et al., 2005).
Miron et al. (2007) compared brown midrib sorghum silage, conventional sorghum silage, and conventional corn silage and found that in vitro DM digestibility was greater for the brown midrib sorghum and corn silage. The DMI per meal was greater for cows fed the higherdigestibility silage, but the number of daily meals was greater for cows fed the lower-digestibility silage. These results agree with Oba and Allen (2000), who observed lower DMI when cows were fed a greater-NDF diet and when the diets contained control rather than brown midrib corn silage. Taylor and Allen (2005) found that cows fed brown midrib corn silage spent $1.7 \mathrm{~min} / \mathrm{meal}$ less than their cohorts fed conventional corn silage, although they had similar meal size. Overall, these studies indicate that forage with greater fiber digestibility is associated with feeding behavior and meal patterns that increase DMI.

Cotanch et al. (2012) fed diets that contained either lower (49 to $53 \%$ of ration DM) or higher silage content (64 to $67 \%$ of ration DM), and, within each forage level, either conventional or brown midrib corn silage was fed to vary the forage NDF digestibility. Eating time was 1 $\mathrm{h}$ greater for cows fed the higher-forage diet containing the conventional corn silage versus those cows consuming the lower-forage diet with brown midrib corn silage. Additionally, whether the cows consumed conventional or brown midrib silage was associated with a difference of $30 \mathrm{~min} / \mathrm{d}$ in time spent eating. The increase in time spent eating with greater forage content and NDF digestibility was almost exactly offset by reduction in lying time, similar to Jiang et al. (2017), as they varied dietary forage content.

Kononoff and Heinrichs (2003) compared the effects of alfalfa silage that varied in geometric mean length from 4.1 to $6.8 \mathrm{~mm}$ and found that daily eating time increased by $36 \mathrm{~min} / \mathrm{d}$ as silage particle size increased. At the same time, DMI decreased by $3.3 \mathrm{~kg} / \mathrm{d}$, indicating that it took the cows longer to consume less DM of more coarsely chopped silage. Similarly, Fernandez and Michalet-Doreau (2002) compared corn silage chopped to either 4.2 or $12.0 \mathrm{~mm}$ theoretical length of cut and observed that time spent eating was reduced by $43 \mathrm{~min} / \mathrm{d}$ for cows fed the finer chopped silage despite similar DMI.

Fernandez et al. (2004) compared the effects of 2 corn silage hybrids varying in NDF digestibility either when finely or coarsely chopped (5 vs. $13 \mathrm{~mm}$ theoretical length of cut, respectively). Regardless of chop length, the hybrid with greater NDF digestibility elicited greater DMI with similar eating, rumination, and chewing times. Bal et al. (2000) compared unprocessed corn silage harvested at $9.5 \mathrm{~mm}$ theoretical length of cut with processed corn silage harvested at $9.5,14.5$, or $19.0 \mathrm{~mm}$ theoretical length of cut using a conventional 
corn hybrid. Although eating, rumination, and chewing times did not differ, greater DMI was observed for processed corn silage compared with unprocessed corn silage. Interestingly, ascension time, the time necessary for a weight to ascend from the bottom of the rumen to the surface, was measured and used as a ruminal mat consistency indicator and longer ascension times were observed for unprocessed or 19.0-mm processed corn silage than the other treatments. These results were related to the greater mean particle length measurements observed for these treatments. To our knowledge, similar studies with corn silage of various hybrid types chopped to a coarser theoretical length of cut that is within the typical range used in the United States (19 to $26 \mathrm{~mm}$ ) are unavailable in the literature and further research is warranted.

Considerable research indicates that feeding higherforage diets, lower-NDF digestibility forages, and longer particle size increase the time needed to consume the feed. How feeding diets of varying forage content, particle size, and NDF digestibility affect the cow's time budget (time required for natural eating, resting, and ruminating behaviors) is a management challenge that requires further research. Greater chewing time during eating and ruminating may well be a primary limiting factor for DMI for high-producing dairy cows (McLeod et al., 1990). Cows with the greatest drive to eat responded most positively in DMI to less-filling alfalfa silage versus more-filling orchardgrass silage when both were the primary dietary fiber source (Voelker Linton and Allen, 2008). Additionally, many cows in the United States are fed in competitive feeding environments and often overstocked at the feed bunk (von Keyserlingk et al., 2012). The USDA National Animal Health Monitoring Service survey of freestall dairy farms reported that $58 \%$ of dairy farms provide less than the recommended $60 \mathrm{~cm} /$ cow of bunk space (USDA, 2010). Under optimal conditions, the dairy cow's daily time budget entails 3 to $5 \mathrm{~h} / \mathrm{d}$ of eating time (Gomez and Cook, 2010). For dairy farms with management that results in highly competitive feeding situations, sufficient time for cows to consume their diet may not be offered, as silage fiber content, digestibility, and particle size vary.

\section{Corn Versus Sorghum Silage: Fiber Digestibility and DMI}

Strategies to improve NDF digestibility in silages are often related to a reduction in the lignin or indigestible NDF concentration and include forage type, hybrid selection, maturity at harvest, and treatment with additives. Improvements in NDF digestibility of corn silage through hybrid selection was reviewed by Ferraretto and Shaver (2015), who found 0.9 and $1.2 \mathrm{~kg} / \mathrm{d}$ greater DMI and milk production, respectively, when cows were fed hybrids of greater NDF digestibility. However, the effects of corn hybrid type on feeding and sorting behavior of dairy cattle has not been reported.

In recent years, sorghum has become an important silage crop for dairy farmers, particularly in regions that have considerable risks for corn silage production, such as delayed planting due to wet soil, elevated summer temperatures, drought, or areas where irrigation is unavailable (Emile et al., 2006; Contreras-Govea et al., 2010). However, the incorporation of sorghum silage in diets of high-producing cows may be challenging. It is typical of sorghum plants to have greater NDF and lignin concentrations than corn plants (Contreras-Govea et al., 2010), which may affect chewing behavior by dairy cows (Grant et al., 1995). In addition, similar to brown midrib hybrids in corn, sorghum brown midrib hybrids with improved fiber digestibility are also available (Bernard and Tao, 2015) to dairy farmers and corn growers and may affect feeding behavior and DMI of dairy cows.

Grant et al. (1995) compared the effects of feeding conventional sorghum silage-, brown midrib sorghum silage-, alfalfa silage-, and corn silage-based diets on chewing behavior of lactating dairy cows. Forages comprised $65 \%$ (DM basis) of the diet and a single forage source was used for each diet. Alfalfa and conventional sorghum diets had lower DMI than brown midrib sorghum. In addition, when expressed per kilogram of NDF intake, rumination was lower for brown midrib sorghum than alfalfa and corn silage. In a follow-up trial of similar design, cows fed corn silage had reduced eating time compared with other silage treatments (Aydin et al., 1999). Furthermore, feeding sorghum silage, either conventional or brown midrib, increased rumination time compared with corn silage. Aydin et al. (1999) conducted a second experiment comparing corn, conventional sorghum, and brown midrib sorghum silage. Diets contained $35 \%$ of treatment forage sources (DM basis) and $17.5 \%$ haycrop silage. No effects of silage source on DMI and chewing behavior were reported.

Table 1 summarizes the effect of conventional and brown midrib sorghum on chewing behavior of dairy cows compared with conventional corn silage. Overall, consumption of DM is limited and eating time is enhanced when cows are fed conventional sorghum, which reflects the greater NDF content and lower NDF digestibility; both effects are exacerbated with high-forage diets. In contrast, brown midrib sorghum offers the potential to maintain or slightly increase DMI compared with corn silage. But, as mentioned previously, this response is inconsistent, particularly for higher-forage 
Table 1. Intake of DM and chewing behavior of lactating cows fed corn, conventional sorghum, and brown midrib sorghum silage ${ }^{1}$

\begin{tabular}{|c|c|c|c|c|c|}
\hline Study & $\begin{array}{l}\text { Forage, } \\
\% \text { of } \mathrm{DM}^{2}\end{array}$ & $\begin{array}{c}\text { Intake, } \\
\%\end{array}$ & $\begin{array}{c}\text { Eating } \\
\text { time, \% }\end{array}$ & $\begin{array}{c}\text { Rumination } \\
\text { time, } \%\end{array}$ & $\begin{array}{l}\text { Chewing } \\
\text { time, \% }\end{array}$ \\
\hline \multicolumn{6}{|l|}{ Conventional sorghum } \\
\hline Aydin et al., 1999 (Exp. 2) & 52.8 & 95.6 & 105.6 & 103.5 & 104.2 \\
\hline Oliver et al., 2004 & 50.0 & 95.5 & 114.9 & 97.0 & 104.4 \\
\hline \multicolumn{6}{|l|}{ Brown midrib sorghum } \\
\hline Aydin et al., 1999 (Exp. 2) & 52.8 & 101.2 & 113.7 & 101.3 & 105.5 \\
\hline Oliver et al., 2004 (BMR-6) ${ }^{3}$ & 50.0 & 103.7 & 97.0 & 103.9 & 101.1 \\
\hline Oliver et al., 2004 (BMR-18) & 50.0 & 96.3 & 114.9 & 94.0 & 102.6 \\
\hline
\end{tabular}

${ }^{1}$ Data presented as percentage of corn silage treatment.

${ }^{2}$ Total dietary forage concentration of the diet; it may not represent specific amount of each forage source.

${ }^{3}$ BMR- 6 = brown midrib sorghum hybrid containing the $b m 6$ gene mutation; BMR-18 = brown midrib sorghum hybrid containing the $b m 18$ gene mutation.

diets. Overall, reduced DMI is accompanied by longer eating time, which is a response that seems consistent across corn and sorghum silage types.

\section{SILAGE PARTICLE SIZE, CHEWING ACTIVITY, AND INGESTED FEED PARTICLE SIZE}

Mertens (1997) summarized data from several studies showing that the chewing time per kilogram of NDF for a range of forages of similar length varied by nearly 2 -fold (111 to $209 \mathrm{~min} / \mathrm{kg}$ of NDF). Their data set included legumes, grasses, and straws commonly fed to dairy cattle and other ruminants. Chewing response is governed by physical as well as chemical attributes of the silage. Important physical properties include particle size, fragility, and rate of particle breakdown when chewed (Casler et al., 1996). Chemical properties include moisture content, which aids in swallowing, lower NDF content, lower lignin concentration, and crosslinking, which is associated with more effective mastication (Rinne et al., 2002).

Recently, Italian researchers focused on the chewing and eating process in dairy cows and observed that cattle tend to chew forages while eating just enough to swallow the bolus (Schadt et al., 2012). Generally, larger feed particles were chewed to a threshold size that was suitable for bolus formation and deglutition. When measured using a combination of wet sieving and image analysis, those researchers found that the swallowed bolus particle size was approximately 10 to $11 \mathrm{~mm}$ (Table 2). Although the offered forages varied from 9.7 to $43.5 \mathrm{~mm}$ in size, the bolus mean size was quite similar. The feeds offered included rye grass hay of various lengths, grass silage, corn silage, and a TMR. These data suggest that feeding long silage or dry hay particles to dairy cows does not necessarily boost par- ticle size in the rumen beyond the size of the swallowed bolus of feed. Some previous research indicated that the particle size of the swallowed bolus is directly related to the forage chemical composition such as lignin, NDF, and moisture content (Rinne et al., 2002), whereas the Schadt et al. (2012) study found that quite different forage NDF content resulted in similar bolus particle size. Importantly, forages that are higher in NDF concentration or have longer particle size effectively lengthen the time required to consume feed. In Schadt et al. (2012), the chews per gram of NDF varied from 0.4 to 3.5. Similar to the effect of dietary silage content and digestibility on eating time, longer particle size serves to lengthen the time needed to consume a meal. Again, depending on feed bunk management and the associated level of competition for feed, having too great a particle size of the forage may be disadvantageous for the cow. Forages with mean particle length greater than 10 to $11 \mathrm{~mm}$ may take the cow longer to process (i.e., chew and swallow), and the management challenge becomes whether or not that extra time at the feed bunk is available.

One major impediment to establishing recommendations for optimal silage or feed particle size has been the variety of methods used to measure particle size (Zebeli et al., 2008). Measures of particle size, size distributions, and physically effective NDF may be substantially affected by the methodology, namely dry, wet, and as-fed sieving as well as horizontal or vertical sieving motion. A ubiquitous tool for measuring silage and TMR particle distributions in the field is the Penn State Particle Separator (Heinrichs and Kononoff, 2013), which entails horizontal shaking of as-fed silage or TMR samples through a series of sieves with 19-, 8-, and 4-mm apertures plus a pan. The 4-mm sieve is used to calculate a physical effectiveness factor (Heinrichs 
and Kononoff, 2013) for use in determining physically effective NDF when assessing TMR or formulating diets. Particles on the 19-mm sieve are effective at stimulating chewing, but also have the greatest potential for sorting by the cow (Kononoff and Heinrichs, 2003). Targets for silage and TMR particle distributions are available in Heinrichs and Kononoff (2013).

\section{SORTING AND SILAGE CHARACTERISTICS}

When the rumen is supplied with a consistent amount of nutrients throughout the day, there should be a more uniform ruminal environment for microbial growth (Van Soest, 1994). In contrast, if the feeding environment encourages fast eating rates (i.e., slug feeding) or selective feeding, be substantial diurnal changes may occur in acid production that lead to SARA and related problems.

Kononoff et al. (2003) fed a TMR containing 57.4\% corn silage that was chopped to a $7.4,7.8,8.3$, or 8.8 $\mathrm{mm}$ geometric mean particle size. As particle size of the silage decreased, DMI increased linearly. At 8, 16, and $24 \mathrm{~h}$ postfeeding, the NDF content of the feed remaining in the feed bunk decreased linearly. The highest degree of sorting was evident for cows fed the $8.8-\mathrm{mm}$ mean particle size TMR. Specifically, the fraction of particles retained on the 19-mm sieve of the Penn State Particle Separator was most likely to be sorted (Kononoff and Heinrichs, 2003).

On commercial farms, although finer chopping or processing of the silage boosts the power required and overall harvest costs, reduced sorting behavior and less time potentially spent at the feed bunk consuming feed provide productive and economic benefits. Sova et al. (2013) found that, under competitive feeding situations, each 2-percentage-unit increase in feed refusal was associated with a $1.3 \%$ increase in sorting; likewise, milk per DMI decreased by $3 \%$ for each $1 \%$ increase in sorting. For the individually fed cow, as in a tiestall, sorting may occur throughout the day but, by $24 \mathrm{~h}$, cows will have consumed a ration that is similar to the TMR initially offered (Maulfair and Heinrichs, 2013). However, in a competitive feeding environment the net effect of sorting over $24 \mathrm{~h}$ will often be detrimental to the ruminal environment.

Cows fed a silage-based TMR in a competitive feeding environment will practice greater sorting (Albright and Arave, 1997) than cows fed in a noncompetitive environment, such as a tiestall. Nonetheless, it seems clear that the fraction of silage TMR particles retained on the 19-mm sieve when using the Penn State Particle Separator is most likely to be sorted, and this fraction should be carefully managed to minimize the potential for sorting.

\section{STARCH DIGESTIBILITY AND FEEDING BEHAVIOR}

The fibrous characteristics of silages, such as content, size, and digestibility, affect ruminal fill, chewing, DMI, and sorting behavior. Some silage sources also contain a significant starch fraction with the potential to substantially influence feed intake and meal patterns. Starch content varies by hybrid, growing conditions, and time of harvest. Several factors influence starch digestibility in silage, including maturity at harvest, processing method, and duration of silage fermentation. A comprehensive review of these factors may be found in companion articles in this special issue (refer to Ferraretto et al., 2018; Kung et al., 2018).

A recent review by Allen et al. (2009) conceptualized DMI regulation via the hepatic oxidation theory and described its potential application to ruminant diets. Briefly, diets formulated to contain greater starch content or ruminal starch digestibility enhance the proportion of propionate in ruminal fluid. Furthermore, the flow of VFA from the rumen to blood is greater, which contributes to greater levels of propionate reaching the liver. If propionate exceeds the liver's glucogenic capac-

Table 2. Particle size of forages, bolus particle size, and required chewing to swallow ${ }^{1}$

\begin{tabular}{|c|c|c|c|c|}
\hline Item & $\begin{array}{c}\text { NDF, } \\
\% \text { of DM }\end{array}$ & $\begin{array}{l}\text { Feed particle } \\
\text { size, mm }\end{array}$ & $\begin{array}{l}\text { Bolus particle } \\
\text { size, mm }\end{array}$ & $\begin{array}{c}\text { Chews per gram } \\
\text { of NDF }\end{array}$ \\
\hline Long rye grass hay & 57.1 & - & 10.3 & 2.6 \\
\hline 50-mm rye hay & 58.6 & 42.2 & 9.9 & 3.5 \\
\hline 8-mm PSPS hay & 59.1 & 25.1 & 10.8 & 1.7 \\
\hline 1.18-mm PSPS hay & 54.2 & 9.7 & 8.1 & 1.9 \\
\hline Grass silage & 53.1 & 13.8 & 11.6 & 0.4 \\
\hline
\end{tabular}

${ }^{1}$ Adapted from Schadt et al. (2012).

${ }^{2}$ PSPS $=$ Penn State Particle Separator (Heinrichs and Kononoff, 2013). 
ity, propionate is oxidized, yielding sufficient ATP to evoke satiety by cerebral stimulation mediated by the vagus nerve.

Although a plausible theory, most studies determining the effects of greater starch content and ruminal starch digestibility on propionate, satiety, and meal patterns were performed with nonforage starchy feedstuffs (for example, Oba and Allen, 2003; Ferraretto et al., 2013). These trials reported a decline in consumption as a result of improved ruminal starch digestibility, without a concomitant decrease in milk yield. However, studies evaluating strategies that increase starch digestibility in silages with reports of feeding behavior are limited. These studies would be particularly important, as some strategies influence starch digestibility and physical characteristics of the fiber fraction simultaneously (i.e., use of kernel processing in corn silage).

Dairy cow response to dietary starch content and fermentability depends on physiological state, which changes throughout the lactation cycle (Allen et al., 2005). Energy partitioning between milk synthesis and body conditioning varies depending on metabolic fuels available and the cow's physiological status. As lactation progresses and milk yield declines, DMI is increasingly dominated by metabolic signals (Allen et al., 2009). Highly fermentable diets often reduce DMI in mid to late lactation, likely from stimulation of hepatic oxidation by propionate (Allen et al., 2009). Increasing the ruminal fermentability of starch by substituting dry corn with high-moisture corn in rations often increases energy intake and partitioning to milk for these cows, which in turn leads to enhanced feed efficiency ( $\mathrm{kg}$ of milk/kg of DMI; Ferraretto et al., 2013).

The content and fermentability of silage starch, or the ratio of NDF to starch in the silage, would be expected to greatly alter fuels available for metabolism. Research has shown that cows vary markedly in their DMI and milk yield response to corn and alfalfa silages and TMR of varying starch and NDF digestibility as a function of milk yield or DIM at the start of an experiment (Voelker et al., 2002; Ivan et al., 2005). Onfarm grouping strategies should take advantage of this variable responsiveness to carbohydrate fermentability. Further research is needed to assess the potential interactions between silage starch fermentability and the feeding environment and their effects of lactation performance and rumen health, particularly as it relates to cow grouping and management decisions throughout lactation.

\section{SILAGE FERMENTATION AND FEED CONSUMPTION}

Weiss et al. (2003) highlighted the nutritional differences between silage and fresh or dried forages, par- ticularly the fermentation end products (i.e., organic acids) and proteolysis-induced NPN fractions (i.e., ammonia-N and amines). Metabolism of silage fermentation end products was previously reported to alter feed consumption and behavior by dairy cows (Mahanna and Chase, 2003; Weiss et al., 2003); however, to estimate individual effects of organic acids or silage $\mathrm{pH}$ has been challenging. Some studies partially replaced silage with hay to assess silage fermentation characteristics or $\mathrm{pH}$, but these were often confounded by forage NDF content and digestibility or other factors known to affect consumption of DM (Allen, 2000). Erdman (1993) reviewed studies evaluating the addition of silage fermentation end products to silage and their effects on DMI and concluded that greater concentrations of acids and the corresponding decrease in $\mathrm{pH}$ limits DMI. Furthermore, consumption of frozen corn forage was greater than corn silage, but addition of fermentation end products to frozen corn forage resulted in similar responses (Shaver et al., 1985).

This information is of particular interest to dairy nutritionists, as extent and profile of fermentation varies based on forage species, adequate ensiling practices, silage moisture concentration, and treatment with microbial inoculants and chemical additives at harvest. Thus, to understand the induced response of individual fermentation end products on consumption and feeding behavior is crucial. Based on the meta-analysis of Huhtanen et al. (2007), potentially negative effects of fermentation end products on DMI were tempered by enhanced nutrient demands of higher-producing animals. These data suggest that, perhaps, for highproducing dairy cows factors other than fermentation end products may act as major intake regulators, but further research is needed.

Finally, little research has evaluated the interaction between silage quality as measured by fermentation end product profile and feed bunk management. However, Mahanna and Chase (2003) pointed out basic management approaches to minimize negative animal responses to poor-quality silage, such as attention to silage bunk life and palatability concerns.

\section{Lactate}

Lactic acid is the primary fermentation end product in silage (McDonald et al., 1991). Understanding lactate metabolism is particularly important when cows are fed silage treated with lactate-producing bacterial inoculants. Kung et al. (2003b) summarized 12 studies evaluating the effects of feeding lactating cows with silage treated with Lactobacillus plantarum MTD1 and found no alterations in consumption of DM. A recent meta-analysis by Oliveira et al. (2017) highlighted that 
silage treated with homofermentative and facultative heterofermentative lactic acid bacterial inoculant had approximately 1 percentage unit greater lactate concentration than untreated silage. Although inoculation enhanced DMI, and hence milk yield by dairy cows (Oliveira et al., 2017), these authors suggested that DMI effects were mediated indirectly by reduced concentration of butyrate, ammonia, and biogenic amines in inoculated silages.

Cows fed alfalfa ensiled with a lactic acid bacterial inoculant tended to have greater total ruminal VFA than their cohorts fed untreated silage, although VFA proportions were not changed (Mohammed et al., 2012). In contrast, acetate-to-propionate ratio decreased when beef steers were fed a corn silage-based diet sprayed with lactic acid (Daniel et al., 2013a). Despite changes in ruminal proportions of VFA, no effects on DMI or chewing behavior were reported. Interestingly, steers fed the lactic acid treatment tended to sort against 8to $19-\mathrm{mm}$ and toward $<8-\mathrm{mm}$ dietary particles (Daniel et al., 2013a).

An inverse relationship between grass silage lactate concentration and DMI (expressed as \% of BW) of growing cattle was reported by Krizsan and Randby (2007); however, negative relationships were also observed between DMI and acetate, propionate, butyrate, ammonia, and biogenic amines in that study. Huhtanen et al. (2002) evaluated the effects of fermentation end products in grass silage on DMI of lactating cows using a data set composed of 21 studies and revealed an inverse relationship to lactate. But, similar to Krizsan and Randby (2007), several other silage fermentation end products were also inversely related to DMI. Interestingly, however, both studies reported no relationship between silage $\mathrm{pH}$ and voluntary DMI, suggesting that these results are driven by fermentation end products rather than $\mathrm{pH}$.

\section{Acetate}

A negative relationship between silage acetate concentration and silage consumption was previously reported in the literature (Wilkins et al., 1971; Anil et al., 1993), suggesting that acetate concentration in silage may contribute to intake regulation (Weiss et al., 2003) via increased osmotic pressure of ruminal contents (Forbes et al., 1992). Reduced DMI due to acetic acid could be related to dietary palatability as well (Buchanan-Smith, 1990).

Epiphytic bacterial fermentation often yields low concentrations of acetic acid (McDonald et al., 1991). Furthermore, a recent meta-analysis revealed that homofermentative and facultative heterofermentative lactic acid bacterial inoculants lessen acetate concentration of ensiled forages (Oliveira et al., 2017). In contrast, the use of Lactobacillus buchneri-based inoculants increased concentration of acetate in corn, grass, and small grain silages to an average of $4 \%$ of DM (Kleinschmit and Kung, 2006). Based on that study, Daniel et al. (2013b) sprayed and mixed acetic acid into a Bermuda grass hay-based diet to simulate a $4 \%$ of DM concentration and fed the forage to mid-lactation dairy cows for 7 wk. Cows fed the acetic acid treatment had lower DMI during wk 2 and 3 of the study only. Although daily eating, ruminating, and chewing time were unaffected by treatment, cows fed the acetic acid diet spent $34 \mathrm{~min}$ less time eating during the $4 \mathrm{~h}$ after morning feeding. Similar results were reported in sheep when acetic acid was added to ryegrass silage (Hutchinson and Wilkins, 1971). Despite greater acetate concentration, cows fed whole-plant barley or alfalfa silage treated with Lactobacillus buchneri-based inoculants had similar DMI to their cohorts fed untreated silage (Taylor et al., 2002; Kung et al., 2003b). In grass silage, however, acetate concentration was inversely related to DMI in growing cattle (Krizsan and Randby, 2007) and lactating cows (Huhtanen et al., 2002).

\section{Propionate}

It is well-established that propionate regulates consumption in ruminant animals to a greater extent than other organic acids (Allen et al., 2009). Although starchy silages may contribute to this scenario, it is related to digestion of starch by rumen bacteria and the corresponding yield of propionate. Propionate concentration in silage is limited (McDonald et al., 1991) and accounts for a marginal fraction of propionate produced in the rumen (Weiss et al., 2003).

Propionic acid is used as an additive, either alone or in combination with other organic acids, due to its fungicidal properties and potential to improve aerobic stability in silage (Kung et al., 2003a), and could influence propionate concentration in silages and thereby feed consumption and feeding behavior of dairy cows. However, previous studies (Kung et al., 1998, 2000) revealed minimal effects on end products of silage fermentation when corn silage was treated with propionic acid-based additives, despite the enhancement in aerobic stability. Importantly, microbial inoculants and other chemical additives are more effective than propionic acid-based additives when treating whole-plant forages (Queiroz et al., 2013). In contrast, treatment of wet by-products with propionic acid-based additives, particularly wet brewers grain, is very effective (Moriel et al., 2016). Although elevated propionate concentration was reported 
in some studies (8\% of DM; Moriel et al., 2016), dietary concentration of these wet by-products are often limited and should not be of any practical concern.

\section{Ethanol}

Weiss et al. (2003) underscored that acetate is the main end product of ethanol metabolism, regardless if metabolized in the rumen or absorbed in the lower gut and metabolized in the liver. Although low concentrations of ethanol are prevalent in most silages (McDonald et al., 1991), it is the main fermentation end product in sugarcane silage (Kung and Stanley, 1982). Elevated concentrations of ethanol were previously reported in silage treated with formic acid (Kung et al., 2003a).

Daniel et al. (2013b) sprayed and mixed ethanol into a Bermuda grass hay-based diet to reach a 5\% DM concentration and observed greater DMI when ethanol mass was properly accounted for in the DM determination. Feeding behavior was unaffected by ethanol concentration in their study. Similar effects on DMI were reported by Randby et al. (1999) when feeding $600 \mathrm{~g}$ of pure ethanol to lactating cows. For comparison, 600 $\mathrm{g}$ of ethanol consumption would be the equivalent to $12 \mathrm{~kg}$ of DM of silage with an ethanol concentration of $5 \%$ of DM.

Ethanol concentration in grass silage was not related to DMI of growing cattle (Krizsan and Randby, 2007) or lactating cows (Huhtanen et al., 2002). Daniel et al. (2013a) conducted 2 studies to evaluate the effect of ethanol on feed intake of beef steers. In the first study, steers were fed a diet containing $60 \%$ corn silage with added ethanol targeted for $2.8 \%$ of DM, but no effects on consumption or chewing behavior were observed. The follow-up study compared a $75 \%$ sugarcane diet. One diet had sugarcane dried and later rehydrated to eliminate fermentation end products. No effects of fermentation end products on eating, ruminating, and chewing activities were observed. Data from these studies highlight that silage containing high levels of ethanol are unlikely to reduce DMI or negatively affect chewing behavior.

\section{Butyrate and Nitrogenous Compounds}

Butyric acid prevalence in silage is a typical sign of poor fermentation, including Clostridia fermentation of sugars and lactic acid (McDonald et al., 1991). In combination with ammonia-N, butyrate may be a good indicator of the presence of amines and gamma-amino butyric acids. Both factors were previously reported to affect DMI in ruminant animals (McDonald et al., 1991; Scherer et al., 2015). Concentration of butyrate is often related to reductions in DMI (Huhtanen et al., 2002;
Krizsan and Randby, 2007). Although butyrate induces ruminal molality, and thereby stimulate osmoreceptors with potential reduction in meal size, other VFA are often reported as more powerful intake regulators (Allen, 2000).

Proteolysis is a common process that occurs even in silage harvested and stored under adequate management (McDonald et al., 1991) and increases in the concentration of NPN compounds as fermentation progresses (i.e., ammonia-N; McDonald et al., 1991; Der Bedrosian et al., 2012). Other end products, however, are yielded with proteolysis in silages by plant and microbial enzymes of various lactic acid-producing bacteria and bacteria of various genera, including Clostridia (i.e., biogenic amines; Krízek, 1993; Silla Santos, 1996).

Although NPN compounds commonly found in silages undergo rapid and extensive ruminal degradation (Weiss et al., 2003), these compounds could alter metabolism and intake regulation in ruminant animals. Weiss et al. (2003) suggested that high-protein silages would be more likely to affect metabolism and intake, particularly if fed at high dietary levels. Ammonia-N concentration in grass silage was reported to be inversely related to DMI in growing cattle (Krizsan and Randby, 2007) and lactating dairy cows (Huhtanen et al., 2002). Increased ammonia- $\mathrm{N}$ concentrations could lead to intake regulation via gamma-amino butyric acid, which is produced from glutamate during ammonia-N clearance in the liver (Scherer et al., 2015).

Potential effects of ammonia-N on starchy silages may be confounded. Starch digestibility increases as fermentation progresses (refer to Kung et al., 2018) due to proteolysis of prolamin protein surrounding starch granules (Hoffman et al., 2011), and starch digestibility is positively related to ammonia- $\mathrm{N}$ concentration in corn silage (Ferraretto et al., 2015) and high-moisture corn (Ferraretto et al., 2014). As mentioned, greater starch digestibility increases propionate yield in the rumen, and thereby may alter intake regulation (Allen et al., 2009). This information is particularly important for development of future DMI prediction equations for ruminant animals fed large levels of silage.

A more in-depth analysis of biogenic amines and gamma-amino butyric acid is provided in a recent comprehensive review by Scherer et al. (2015). Briefly, Scherer et al. (2015) underscored that research addressing the effect of biogenic amines on DMI is contradictory and further research is warranted. Although biogenic amines can be produced in well-preserved silages (Scherer et al., 2015), perhaps with adequate sealing, packing, and microbial inoculation this issue may be avoided. For example, a study by Nishino et al. (2007) found that microbial inoculants containing Lactobacillus casei and Lactobacillus buchneri attenuate biogenic 
amines production in grass silage, maize silage, and TMR. In poorly fermented silages, however, the presence of Clostridia may increase amine concentration (McDonald et al., 1991). Ruminal microbes metabolize amines into ammonia (Weiss et al., 2003), but, similar to other nitrogenous compounds, this metabolism is related to previous exposure and gradual adaptation.

\section{CONCLUSIONS}

Diets containing high forage content, especially if the fiber is lower in digestibility or has longer chop length, require greater time to eat. Recent evidence suggests that cows chew feed while eating to a relatively uniform size before swallowing the bolus. Feeding a diet composed of silages that creates the need for more chewing while eating may result in a trade-off between standing time at the feed bunk and resting time. Longer forage particle length also contributes to sorting. Many silages also contain substantial levels of starch of varying digestibility. It is well established with concentrate feeds that starch fermentability influences ruminal propionate concentrations and, consequently, feeding behavior and DMI. How the starch characteristics of silages affect meal patterns and DMI within specific feeding environments across an entire lactation merits further study. Finally, the influence of silage fermentation end products on feeding behavior and DMI is well documented, although the specific mechanism in many cases has not been elucidated.

\section{REFERENCES}

Albright, J. L., and C. W. Arave. 1997. The Behavior of Cattle. CAB International, New York, NY.

Allen, M. S. 2000. Effects of short-term regulation of feed intake by lactating dairy cattle. J. Dairy Sci. 83:1598-1624.

Allen, M. S., B. J. Bradford, and K. J. Harvatine. 2005. The cow as a model to study food intake regulation. Annu. Rev. Nutr. 25:523547.

Allen, M. S., B. J. Bradford, and M. Oba. 2009. The hepatic oxidation theory of the control of feed intake and its application to ruminants. J. Anim. Sci. 87:3317-3334.

Anil, M. H., J. N. Mbanya, H. W. Symonds, and J. M. Forbes. 1993. Responses in the voluntary intake of hay or silage by lactating cows to intraruminal infusions of sodium acetate or sodium propionate, the tonicity of rumen fluid or rumen distension. Br. J. Nutr. 69:699-712.

Aydin, G., R. J. Grant, and J. O'Rear. 1999. Brown midrib sorghum in diets for lactation cows. J. Dairy Sci. 82:2127-2135.

Bach, A., N. Valls, A. Sloans, and T. Torrent. 2008. Associations between nondietary factors and dairy herd performance. J. Dairy Sci. 91:3259-3267.

Bal, M. A., R. D. Shaver, A. G. Jirovec, K. J. Shinners, and J. G. Coors. 2000. Crop processing and chop length of corn silage: Effects on intake, digestion, and milk production by dairy cows. J. Dairy Sci. 83:1264-1273.

Beauchemin, K. A. 1991. Ingestion and mastication of feed by dairy cattle. Vet. Clin. North Am. Food Anim. Pract. 7:439-463.

Bernard, J. K., and S. Tao. 2015. Short communication: Production response of lactating dairy cows to brachytic forage sorghum silage compared with corn silage from first or second harvest. J. Dairy Sci. 98:8994-9000.

Buchanan-Smith, J. G. 1990. An investigation into palatability as a factor responsible for reduced intake of silage by sheep. Anim. Prod. 50:253-260.

Casler, M. D., D. K. Schneider, and D. K. Combs. 1996. Development and application of a selection criterion for particle size breakdown of smooth bromegrass leaves. Anim. Feed Sci. Technol. 61:57-71.

Contreras-Govea, F., M. A. Marsalis, L. M. Lauriault, and B. W. Bean. 2010. Forage sorghum nutritive value: A review. Forage Grazinglands https://doi.org/10.1094/FG-2010-0125-01-RV.

Cotanch, K. W., C. Kokko, H. M. Dann, J. W. Darrah, and R. J. Grant. 2012. Amount and digestibility of NDF affects rumen nutrient pool sizes and passage kinetics of dairy cows. J. Dairy Sci. 95(Suppl. 1):181. (Abstr.)

Daniel, J. L. P., R. C. Amaral, R. S. Goulart, M. Zopollatto, V. P. Santos, S. G. Toledo Filho, E. H. Cabezas-Garcia, J. R. Lima, M. C. Santos, and L. G. Nussio. 2013a. Short-term effects of silage volatile compounds on feed intake and digestion in beef cattle. J. Anim. Sci. 91:2321-2331.

Daniel, J. L. P., R. C. Amaral, A. Sa Neto, E. H. Cabezas-Garcia, A. W. Bispo, M. Zopollatto, T. L. Cardoso, M. H. F. Spoto, F. A. P. Santos, and L. G. Nussio. 2013b. Performance of dairy cows fed high levels of acetic acid or ethanol. J. Dairy Sci. 96:398-406.

Der Bedrosian, M. C., L. Kung Jr., and K. E. Nestor Jr.. 2012. The effects of hybrid, maturity and length of storage on the composition and nutritive value of corn silage. J. Dairy Sci. 95:5115-5126.

Emile, J. C., M. Al Rifai, X. Charrier, P. Leroy, and Y. Barriere. 2006. Grain sorghum silages as an alternative to irrigated maize silage. Grassl. Sci. Eur. 11:80-82.

Erdman, R. A. 1993. Silage fermentation characteristics affecting feed intake. Pages 210-219 in Silage Production. NE Reg. Agric. Eng. Serv., Ithaca, NY.

Fernandez, I., C. Martin, M. Champion, and B. Michalet-Doreau. 2004. Effect of corn hybrid and chop length of whole-plant corn silage on digestion and intake by dairy cows. J. Dairy Sci. 87:1298-1309.

Fernandez, I., and B. Michalet-Doreau. 2002. Effect of maturity stage and chopping length of maize silage on particle size reduction in dairy cows. Anim. Res. 51:445-454.

Ferraretto, L. F., P. M. Crump, and R. D. Shaver. 2013. Effect of cereal grain type and corn grain harvesting and processing methods on intake, digestion and milk production by dairy cows through a meta-analysis. J. Dairy Sci. 96:533-550.

Ferraretto, L. F., and R. D. Shaver. 2015. Effects of whole-plant corn silage hybrid type on intake, digestion, ruminal fermentation, and lactation performance by dairy cows through a meta-analysis. J. Dairy Sci. 98:2662-2675.

Ferraretto, L. F., R. D. Shaver, and B. D. Luck. 2018. Silage review: Recent advances and future technologies for whole-plant and fractionated corn silage harvesting. J. Dairy Sci. 101:3937-3951. https://doi.org/10.3168/jds.2017-13728.

Ferraretto, L. F., R. D. Shaver, S. Massie, R. Singo, D. M. Taysom, and J. P. Brouillette. 2015. Effect of ensiling time and hybrid type on fermentation profile, nitrogen fractions and ruminal in vitro starch and NDF digestibility in whole-plant corn silage. Prof. Anim. Sci. 31:146-152.

Ferraretto, L. F., K. Taysom, D. M. Taysom, R. D. Shaver, and P. C. Hoffman. 2014. Relationships between dry matter content, ensiling, ammonia-nitrogen, and ruminal in vitro starch digestibility in high-moisture corn samples. J. Dairy Sci. 97:3221-3227.

Forbes, J. M., J. N. Mbanya, and M. H. Anil. 1992. Effects of intraruminal infusions of sodium acetate and sodium chloride on silage intake by lactating cows. Appetite 19:293-301.

Gomez, A., and N. B. Cook. 2010. Time budgets of lactating dairy cattle in commercial freestall herds. J. Dairy Sci. 93:5772-5781.

Grant, R. J., and J. L. Albright. 2001. Effect of animal grouping on feeding behavior and intake of dairy cattle. J. Dairy Sci. 84(E. Suppl.):156-163.

Grant, R. J., S. G. Haddad, K. J. Moore, and J. F. Pedersen. 1995. Brown midrib sorghum silage for midlactation dairy cows. J. Dairy Sci. 78:1970-1980. 
Heinrichs, J., and P. J. Kononoff. 2013. Penn State Particle Separator. DSE 2013-186. Department of Dairy and Animal Science, Penn State University, University Park. Accessed Jan. 5, 2017. http:// extension.psu.edu/animals/dairy/nutrition/forages/forage-quality -physical/separator.

Hoffman, P. C., N. M. Esser, R. D. Shaver, W. K. Coblentz, M. P Scott, A. L. Bodnar, R. J. Schmidt, and R. C. Charley. 2011. Influence of ensiling time and inoculation on alteration of the starchprotein matrix in high-moisture corn. J. Dairy Sci. 94:2465-2474.

Huhtanen, P., H. Khalili, J. I. Nousiainen, M. Rinne, S. Jaakkola, T. Heikkila, and J. Nousiainen. 2002. Prediction of the relative intake potential of grass silage by dairy cows. Livest. Prod. Sci. 73:111-130.

Huhtanen, P., M. Rinne, and J. Nousiainen. 2007. Evaluation of the factors affecting silage intake of dairy cows: A revision of the relative silage dry-matter index. Animal 1:758-770.

Hutchinson, K. J., and R. J. Wilkins. 1971. The voluntary intake of silage by sheep. 2. The effects of acetate on silage intake. J. Agric. Sci. $77: 539-543$.

Ivan, S. K., R. J. Grant, D. Weakley, and J. Beck. 2005. Comparison of a corn silage hybrid with high cell-wall content and digestibility with a hybrid of lower cell-wall content on performance of Holstein cows. J. Dairy Sci. 88:244-254.

Jensen, L. M., B. Markussen, N. I. Nielsen, E. Nadeau, M. R. Weisbjerg, and P. Norgaard. 2016. Description and evaluation of a net energy intake model as a function of dietary chewing index. J. Dairy Sci. 99:8699-8715.

Jensen, M. B., L. J. Pedersen, and L. Munksgaard. 2005. The effect of reward duration on demand functions for rest in dairy heifers and lying requirements as measured by demand functions. Appl. Anim. Behav. Sci. 90:207-217.

Jiang, F. G., X. Y. Lin, Z. G. Yan, Z. Y. Hu, G. M. Liu, Y. D. Sun X. W. Liu, and Z. H. Wang. 2017. Effect of dietary roughage level on chewing activity, ruminal $\mathrm{pH}$, and saliva secretion in lactating Holstein cows. J. Dairy Sci. 100:2660-2671.

Kleinschmit, D. H., and L. Kung. 2006. A meta-analysis of the effects of Lactobacillus buchneri on the fermentation and aerobic stability of corn and grass and small-grain silages. J. Dairy Sci. 89:4005-4013

Kononoff, P. J., and A. J. Heinrichs. 2003. The effect of reducing alfalfa haylage particle size on cows in early lactation. J. Dairy Sci. $86: 1445-1457$.

Kononoff, P. J., A. J. Heinrichs, and H. A. Lehman. 2003. The effect of corn silage particle size on eating behavior, chewing activities, and rumen fermentation in lactating dairy cows. J. Dairy Sci. 86:3343-3353

Krízek, M. 1993. Biogenic amines in silage. 1. The occurrence of biogenic amines in silage. Arch. Tierenahr. 43:169-177.

Krizsan, S. J., and A. T. Randby. 2007. The effect of fermentation quality on the voluntary intake of grass silage by growing cattle fed silage as the sole feed. J. Anim. Sci. 85:984-996.

Kung, L., Jr., J. R. Robinson, N. K. Ranjit, J. H. Chen, C. M. Golt, and J. D. Pesek. 2000. Microbial populations, fermentation endproducts, and aerobic stability of corn silage treated with ammonia or a propionic acid-based preservative. J. Dairy Sci. 83:1479-1486.

Kung, L., Jr., and R. Shaver. 2001. Interpretation and use of silage fermentation analysis reports. Focus on forage. vol. 3, no. 13. Accessed Jan. 15, 2017. http://fyi.uwex.edu/forage/interpretation -and-use-of-silage-fermentation-analysis-reports.

Kung, L., Jr., R. Shaver, R. J. Grant, and R. J. Schmidt. 2018. Silage review: Interpretation of chemical, microbial, and organoleptic components of silages. J. Dairy Sci. 101:4020-4033. https://doi .org $/ 10.3168 /$ jds.2017-13909.

Kung, L., Jr., A. C. Sheperd, A. M. Smagala, K. M. Endres, C. A. Bessett, N. K. Ranjit, and J. L. Glancey. 1998. The effect of preservatives based on propionic acid on the fermentation and aerobic stability of corn silage and a total mixed ration. J. Dairy Sci. 81:1322-1330.

Kung, L., Jr., and R. W. Stanley. 1982. Effect of stage of maturity on the nutritive value of whole-plant sugarcane preserved as silage. J. Anim. Sci. 54:689-696.
Kung, L., Jr., M. R. Stokes, and C. J. Lin. 2003a. Silage additives. Pages 305-360 in Silage Science and Technology. Agronomy Monograph No. 42. ASA-CSSA-SSA, Madison, WI.

Kung, L., Jr., C. C. Taylor, M. P. Lynch, and J. M. Neylon. 2003b. The effect of treating alfalfa with Lactobacillus buchneri 40788 on silage fermentation, aerobic stability, and nutritive value for lactating dairy cows. J. Dairy Sci. 86:336-343.

Mahanna, W., and L. E. Chase. 2003. Practical applications and solutions to silage problems. Pages 855-895 in Silage Science and Technology. Agronomy Monograph No. 42. ASA-CSSA-SSA, Madison, WI

Maulfair, D. D., and A. J. Heinrichs. 2013. Effects of varying forage particle size and fermentable carbohydrates on feed sorting, ruminal fermentation, and milk and component yields of dairy cows. J. Dairy Sci. 96:3085-3097.

McDonald, P., A. R. Henderson, and S. J. E. Heron. 1991. The Biochemistry of Silage. 2nd ed. Chalcombe Publ., Marlow, UK.

McLeod, M. N., P. M. Kennedy, and D. J. Minson. 1990. Resistance of leaf and stem fractions of tropical forage to chewing and passage in cattle. Br. J. Nutr. 63:105-119.

Mertens, D. R. 1997. Creating a system for meeting the fiber requirement of dairy cows. J. Dairy Sci. 80:1463-1481.

Miron, J., E. Zuckerman, G. Adin, R. Solomon, E. Shoshani, M. Nikbachat, E. Yosef, A. Zenou, Z. Weinberg, Y. Chen, I. Halachmi, and D. Ben-Ghedalia. 2007. Comparison of two forage sorghum varieties with corn and the effect of feeding their silages on eating behavior and lactation performance of dairy cows. Anim. Feed Sci. Technol. 139:23-39.

Mohammed, R. D. M. Stevenson, K. A. Beauchemin, R. E. Muck, and P. J. Weimer. 2012. Changes in ruminal bacterial community composition following feeding of alfalfa ensiled with a lactic acid bacterial inoculant. J. Dairy Sci. 95:328-339.

Moriel, P., M. B. Piccolo, L. F. A. Artioli, G. S. Santos, M. H. Poore, and L. F. Ferraretto. 2016. Method of propionic acid-based preservative addition and its effects on nutritive value and fermentation characteristics of wet brewers grain ensiled in the summertime. Prof. Anim. Sci. 32:591-597.

Munksgaard, L., M. B. Jensen, L. J. Pedersen, S. W. Hansen, and L. Matthews. 2005. Quantifying behavioural priorities - Effects of time constraints on behaviour of dairy cows, Bos taurus. Appl. Anim. Behav. Sci. 92:3-14.

Nishino, N., H. Hattori, H. Wada, and E. Touno. 2007. Biogenic amine production in grass, maize and total mixed ration silages inoculated with Lactobacillus casei and Lactobacillus buchneri. J. Appl. Microbiol. 103:325-332.

Oba, M., and M. S. Allen. 2000. Effects of brown midrib 3 mutation in corn silage on productivity of dairy cows fed two concentrations of dietary neutral detergent fiber: 1 . Feeding behavior and nutrient utilization. J. Dairy Sci. 83:1333-1341.

Oba, M., and M. S. Allen. 2003. Effects of corn grain conservation method on feeding behavior and productivity of lactating dairy cows at two dietary starch concentrations. J. Dairy Sci. 86:174183.

Oliveira, A. S., Z. G. Weinberg, I. M. Ogunade, A. A. P. C. Cervantes, K. G. Arriola, Y. Jiang, D. Kim, X. Li, M. C. M. Gonçalves, D. Vyas, and A. T. Adesogan. 2017. Meta-analysis of the effects of inoculation with homofermentative and facultative heterofermentative lactic acid bacteria on silage fermentation, aerobic stability, and the performance of dairy cows. J. Dairy Sci. 100:4587-4603.

Oliver, A. L., R. J. Grant, J. F. Pedersen, and J. O'Rear. 2004. Comparison of brown midrib- 6 and -18 forage sorghum with conventional sorghum and corn silage in diets of lactating dairy cows. J. Dairy Sci. 87:637-644.

Queiroz, O. C. M., K. G. Arriola, J. L. P. Daniel, and A. T. Adesogan. 2013. Effects of 8 chemical and bacterial additives on the quality of corn silage. J. Dairy Sci. 96:5836-5843.

Randby, A. T., I. Selmer-Olsen, and L. Baevre. 1999. Effect of ethanol in feed on milk flavor and chemical composition. J. Dairy Sci. $82: 420-428$ 
Rinne, M., P. Huhtanen, and S. Jaakkola. 2002. Digestive processes of dairy cows fed silages harvested at four stages of grass maturity. J. Anim. Sci. 80:1986-1998.

Silla Santos, M. H. 1996. Biogenic amines: Their importance in foods. Int. J. Food Microbiol. 29:213-231.

Schadt, I., J. D. Ferguson, G. Azzaro, R. Petriglieri, M. Caccamo, P. Van Soest, and G. Licitra. 2012. How do dairy cows chew? Particle size analysis of selected feeds with different particle length distributions and of respective ingested bolus particles. J. Dairy Sci. 95:4707-4720.

Scherer, R., K. Gerlach, and K.-H. Sudekum. 2015. Biogenic amines and gamma-amino butyric acid in silages: Formation, occurrence and influence on dry matter intake and ruminant production. Anim. Feed Sci. Technol. 210:1-16.

Shaver, R. D., R. A. Erdman, A. M. O'Connor, and J. H. Vandersall. 1985. Effects of silage $\mathrm{pH}$ on voluntary intake of corn silage and alfalfa haylage. J. Dairy Sci. 68:338-346.

Sova, A. D., S. J. LeBlanc, B. W. McBride, and T. J. DeVries. 2013. Associations between herd-level management practices, feed sorting, and milk production in freestall dairy farms. J. Dairy Sci. 96:4759-4770.

Taylor, C. C., and M. S. Allen. 2005. Corn grain endosperm type and brown midrib 3 corn silage: Feeding behavior and milk yield of lactating cows. J. Dairy Sci. 88:1425-1433.

Taylor, C. C., N. J. Ranjit, J. A. Mills, J. M. Neylon, and L. Kung. 2002. The effect of treating whole-plant barley with Lactobacillus buchneri 40788 on silage fermentation, aerobic stability, and nutritive value for dairy cows. J. Dairy Sci. 85:1793-1800.
USDA. 2010. Facility characteristics and cow comfort on US dairy operations, 2007. USDA, Plant and Animal Health Inspection Service, Center for Epidemiology and Animal Health, Fort Collins, $\mathrm{CO}$

Van Soest, P. J. 1994. Nutritional Ecology of the Ruminant. 2nd ed. Comstock Publ. Assoc., Ithaca, NY.

Voelker Linton, J. A., and M. S. Allen. 2008. Nutrient demand interacts with forage family to affect intake and digestion responses in dairy cows. J. Dairy Sci. 91:2694-2701.

Voelker, J. A., G. M. Burato, and M. S. Allen. 2002. Effects of pretrial milk yield on response of feed intake, digestion, and production to dietary forage concentration. J. Dairy Sci. 85:2650-2661.

von Keyserlingk, M. A. G., A. Barrientos, K. Ito, E. Galo, and D. M. Weary. 2012. Benchmarking cow comfort on North American free stall dairies: Lameness, leg injuries, lying time, facility design, and management for high-producing Holstein dairy cows. J. Dairy Sci. 95:7399-7408.

Weiss, W. P., D. G. Chamberlain, and C. W. Hunt. 2003. Feeding silages. Pages 469-504 in Silage Science and Technology. Agronomy Monograph No. 42. ASA-CSSA-SSA, Madison, WI

Wilkins, R. J., K. J. Hutchinson, R. F. Wilson, and C. E. Harris. 1971. The voluntary intake of silage by sheep. 1. Interrelationships between silage composition and intake. J. Agric. Sci. 77:531-537.

Zebeli, Q., J. Dijkstra, M. Tafaj, H. Steingass, B. N. Ametaj, and W. Drochner. 2008. Modeling the adequacy of dietary fiber in dairy cows based on the responses of ruminal $\mathrm{pH}$ and milk fat production to composition of the diet. J. Dairy Sci. 91:2046-2066. 